\title{
Effectiveness of Combination Myofascial Release and Kinesio Taping Intervention on Range of Motion Improvement in Elderly with Knee Osteoarthritis
}

\author{
Afif Zainuri Wafiq ${ }^{1 *}$, Atika Yulianti ${ }^{1}$
}

\begin{abstract}
Introduction: Knee Osteoarthritis is a condition that frequently occurs in elderly which has a major impact on the elderly's disability. As a degenerative disease, knee osteoarthritis occurs due to cartilage damage which is then accompanied by inflammation, pain, stiff joints and muscles thereby limiting the range of motion. This research aims to compare the effect of Kinesio taping and a combination of myofascial release and Kinesio taping intervention on ROM improvement in elderly with knee osteoarthritis.

Methods: This study applies a quasi-experimental design with a non-equivalent group approach. Goniometer is applied as a measurement instrument. 25 people participated in this study who were recruited through purposive sampling. The sample was then divided into 2 groups which were given treatment 3 times a week in one month. The control group with Kinesio Taping treatment

treatment of myofacial release and Kinesio taping consisted of 11 samples. Furthermore, data analysis was performed with the Shapiro Wilk test, Wilcoxon rank test, and the Mann-Whitney test using SPSS version 25.

Results: The comparison test results show that the significance value of $p$ yields $0.6>0.05$, therefore $H_{1}$ is rejected, and $H_{0}$ is accepted. The interpretation of these results is that there is no significant difference between the effects of Kinesio taping and the combination of myofacial release and Kinesio taping on increasing ROM in the elderly with the risk of knee osteoarthritis.

Conclusion: This study shows that there is no significant difference in the effect of the treatment of Kinesio taping and the combination of myofacial release and Kinesio taping in increasing ROM in the elderly with osteoarthritis.
\end{abstract} consisted of 14 samples and the case group with a combination
${ }^{1}$ Physiotherapy Department; Faculty of Health Sciences; Universitas Muhammadiyah Malang
*Corresponding Author: Afif Zainuri Wafiq; Physiotherapy Department; Faculty of Health Sciences; Universitas Muhammadiyah Malang; zainuri.afif@gmail.com

Received : 2020-02-19 Accepted : 2020-04-15 Published: 2020-05-15

Keywords: elderly, Kinesio taping, knee osteoarthritis, myofascial release.

Cite this Article: Wafiq, A.Z., Yulianti, A. 2020. Effectiveness of Combination Myofascial Release and Kinesio Taping Intervention on Range of Motion Improvement in Elderly with Knee 0steoarthritis. Physical Therapy Journal of Indonesia 1(1): 13-16.

\section{INTRODUCTION}

The aging process is started from the beginning until the end of every people life phases, it is not only in a certain period. ${ }^{1}$ A problem commonly suffered by elderly is knee arthritis disease as caused by degenerative process on psychological. This disease is also known as osteoarthritis. Furthermore, elderly commonly has a health problem in the form of weakness, limitations and disability in physical aspect, therefore the elderly's life quality is decreasing. ${ }^{2}$

Osteoarthritis is a kind of chronic joint disorder which occurs due to the weakening and thinning on the joint cartilage structure as followed by osteophytes formation. ${ }^{3}$ Commonly, osteoarthritis can suffer in several joints, such as: hip and knee joints. In Indonesia, based on radiologically prevalence, there are $8,1 \%$ osteoarthritis patients of total population. Knee osteoarthritis in Indonesia is reaching to $15,5 \%$ of male and $12,7 \%$ of female. ${ }^{4}$ Furthermore, there are estimated 1-2 million elderly suffered disability due to osteoarthritis. Osteoarthritis can lead to disability as an effect of joint pain, inflammation and stiffness. ${ }^{5}$

In this research, the researcher investigates the effect on the combination of myofascial release and Kinesio taping intervention in improving ROM on osteoarthritis knee. According to Kase et al., ${ }^{6}$ Kinesio taping can support the overcoming natural process by facilitating the nervous and circulatory systems. The Kinesio taping application in improving ROM enrolls to add the muscle flexibility and muscle strength, additionally it also can reduce the pain and spasm. ${ }^{7}$ Besides, Werenski ${ }^{8}$ stated that myofascial release technique can support to release the adhesion or fascia adhesion in the muscle area. This technique is quiet effective in reducing tissue pain as combined with another technique. Furthermore, this technique also can reduce edema and accelerate the recovery of posttraumatic muscle injury, also improve the flexibility of injured joints. 


\section{METHODS}

This research is conducted in Puskesmas Kendal Kerep, Malang, Indonesia during 2 months. Furthermore, the respondents are involving 25 people which consist of 23 female and 2 male respondents.

The research design employed in this research was Quasi-experimental with non-equivalent group design. This method aimed at investigating the effect of intervention and control group by using pretest and posttest. ${ }^{9}$ While the data collection was using purposive sampling as the sample collection technique with inclusion and exclusion criteria. Furthermore, the control group was only given Kinesio taping which involved 14 respondents, whereas the intervention group was given the combination of myofascial release and Kinesio taping which involved 11 respondents. In addition, the instrument of this research applied goniometer. The data analysis of this research was using Wilcoxon signed ranked test and MannWhitney test method.

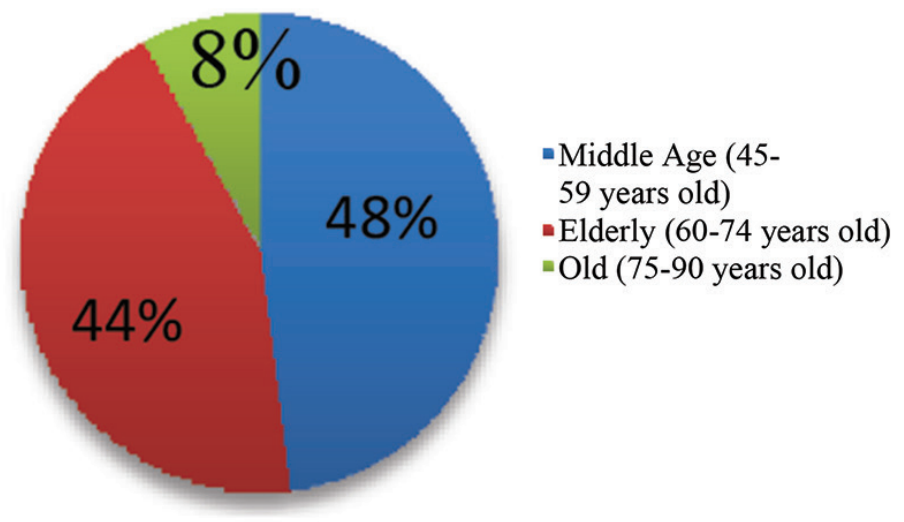

Figure 1. The Sample Distribution based on Age

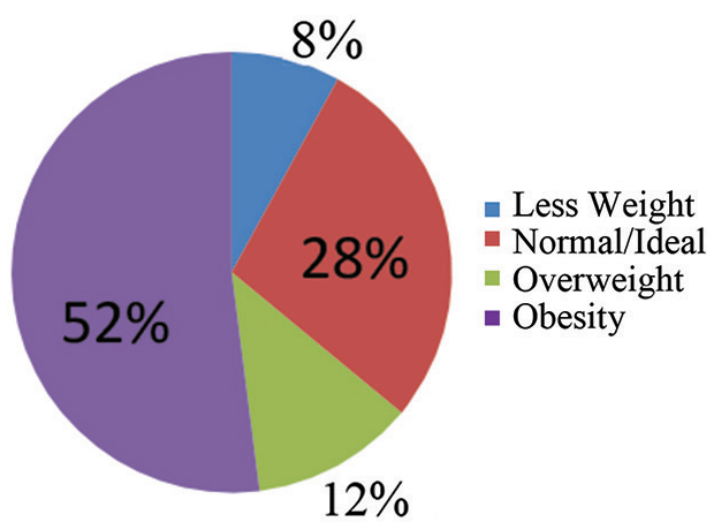

Figure 2. The Sample Distribution based on Body Mass Index (BMI)

\section{RESULTS}

The obtained sample characteristic was covering age range, body mass index (BMI), and gender. The characteristics result of 15 respondents could be seen in the Figure 1.

The sample distribution based on age involved 25 respondents of posyandu lansia RW 3 \& 4 in Polehan district Malang. The characteristic was covering elderly aged 47-79 years old. Based on the data, the sample could be classified into 3 categories, namely: Middle age (45-59 years old) counted $48 \%$ or 12 respondents, Elderly (60-74 years old) counted $44 \%$ or 11 respondents, and Old ( $\geq 75$ years old) counted $8 \%$ or 2 respondents.

The sample was taken based on the critical degenerative process occurred which is occurred on elderly. Thus, elderly experiences the reduction of body function structural and followed by reduction of body endurance.10 In line with Poole A.R,11 statement that osteoarthritis is a degenerative disease which is commonly suffered by people aged $\geq 40$ years old, the patient population will increase based on the age.

The sample distribution based on BMI was classified into 4 categories, namely: Less Weight was counted 2 respondents or $8 \%$ (with $<18,5$ in BMI value), Normal/Ideal was counted 7 respondents or $28 \%$ (with $\geq 18,5$ - $<24,9$ in BMI value), Overweight was counted 3 respondents or $12 \%$ (with $\geq 25-<$ 27 in BMI value) and Obesity was counted 13 respondents or $52 \%$ (with $\geq 27$ in $\mathrm{BMI}$ value). Eylen AA stated that weight is a strong risk factor causing knee osteoarthritis. ${ }^{12}$ Biomechanically, the fulcrum of obesity body weight would move to the medial, moreover the joints became imbalance and joint cartilage became worn out. Therefore, the overweight and obesity could be a risk factor of knee osteoarthritis. ${ }^{13}$

The sample distribution based on gender was classified into: Male (2 respondents or $8 \%$ ), and Female (23 respondents or $92 \%$ ). As a result, the mean value of sample characteristic based on gender was showed that female was more risking in suffering knee osteoarthritis as counted 23 respondents (92\%). In line with the aging theory of Reksoprodjo which stated that when females are experiencing menopause, their estrogen hormone will slightly have decreased. ${ }^{14}$ Estrogen hormone is functioned to synthesize chondrocytes in the bone matrix. If there is an estrogen reduction, it could affect the synthesis of chondrocytes which will cause lysosomes activity to increase and cause osteoarthritis. ${ }^{15}$

The Table 1 showed that the statistical result of ROM flexi knee before given intervention was 
resulting $104^{\circ}$, while the value after given Kinesio taping application was resulting $113,2^{\circ}$, whereas the value of Sig. (2-tailed) was 0,00 . Therefore, the conclusion showed that the value of $\mathrm{P}<0,05$, which meant that $\mathrm{H}_{1}$ was accepted or there was an effect of Kinesio taping application towards ROM improvement on elderly with knee osteoarthritis risk.

The Table 2 showed that the statistical result of ROM flexi knee before given intervention was resulting $108,9^{\circ}$. While the effect test using

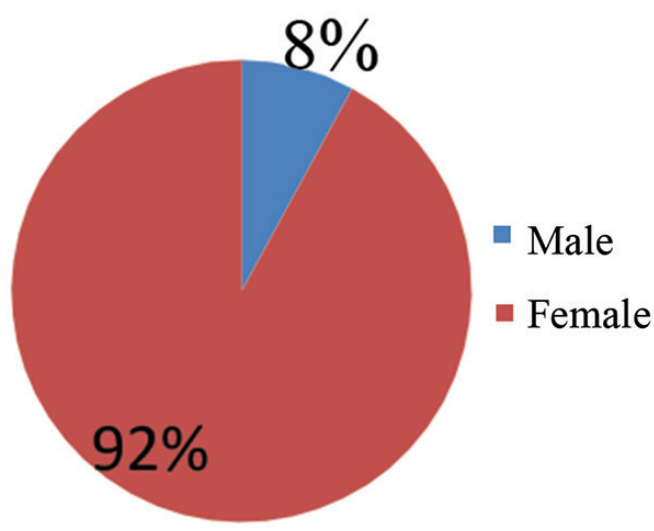

Figure 3. The Sample Distribution based on Gender

Table 1. Wilcoxon Test Result on Control Group

\begin{tabular}{cccccc}
\hline Intervention & \multicolumn{2}{c}{ Mean } & & $\begin{array}{c}\text { Sig. } \\
\text { (2-tailed) }\end{array}$ & $\mathbf{a}$ \\
& Pre & Post & $\mathbf{N}$ & & \\
\hline $\begin{array}{c}\text { Kinesio } \\
\text { taping }\end{array}$ & 104 & 113.2 & 14 & 0.00 & 0.05 \\
\hline
\end{tabular}

Table 2. Wilcoxon Test Result on Intervention Group

\begin{tabular}{|c|c|c|c|c|c|}
\hline \multirow[b]{2}{*}{ Intervention } & \multicolumn{2}{|c|}{ Mean } & \multirow[b]{2}{*}{$\mathbf{N}$} & \multirow[b]{2}{*}{ Sig. (2-tailed) } & \multirow[b]{2}{*}{$a$} \\
\hline & Pre & Post & & & \\
\hline $\begin{array}{c}\text { Kinesio taping } \\
+ \\
\text { Myofascial release }\end{array}$ & 100.9 & 108.9 & 11 & 0.04 & 0.05 \\
\hline
\end{tabular}

Table 3. Mann-Whitney Test Result

\begin{tabular}{lccc}
\multicolumn{1}{c}{ Groups } & $\mathbf{n = 2 5}$ & Sig.(2-tailed) & $\mathbf{a}$ \\
\hline Kinesio taping & 11 & & \\
$\begin{array}{l}\text { Kinesio taping + Myofacial } \\
\text { release }\end{array}$ & 14 & 0,64 & 0,05 \\
\hline
\end{tabular}

Wilcoxon signed test was resulting the value of $\mathrm{P}$ $=0,04$. In conclusion, the result showed that the value of $\mathrm{P}<0,05$ or $\mathrm{H}_{1}$ was accepted, which meant that there was an effect on the combination of myofascial release and Kinesio taping intervention.

The comparative test of both intervention groups was using Mann Whitney with the value of $P=0,64$ and $\alpha=0,05$. The result on table 3 showed that the value of $\mathrm{P}>0,05$, which meant that $\mathrm{H}_{0}$ was accepted and $\mathrm{H}_{1}$ was rejected. Inconclusion, there was no effect on the addition of myofascial release to Kinesio taping application towards ROM improvement on the elderly with knee osteoarthritis risk.

\section{DISCUSSION}

In knee osteoarthritis, the joint instability occurs due to overuse on the muscles area to reduce pressure on the knee joint, thereby it can be reducing muscle strength. The Kinesio taping application can create the space between the skin and muscles, because there is a different pull when moving. As a result, it can reduce the pressure and tension on the soft tissue around the knee joint which leads to the reduction of osteoarthritis symptoms.16 The touch that occurs in the Kinesio taping application activates mechanoreceptor that can stimulate the A-beta fiber. Then, it will activate substantia gelatinosa (SG), inhibits the stimulation of A-delta fiber, and $\mathrm{C}$ as a nociceptive carrier, therefore the stimulation of pain to the central nerve or brain will be inhibited. ${ }^{17}$ The Kinesio taping effect application will make the muscles facilitated lightly. Therefore, the muscle strength will increase and result concentric pull on the muscle fascia which can stimulate the improvement of muscle contraction although the increases are not quite large. ${ }^{18}$

The myofascial release intervention refers to fascia stretching, it is aimed to release the adhesion between fascia, integument, muscles, and bone. Therefore, the fascia flexibility is improving. The improved fascia flexibility can reduce spasm on the extrafusal tissue. When the spasm reducing, inflammation of muscle spindles will also reduce, thus the nerve responds to prevent the acetylcholine release. This condition will normalize the blood circulation, so the oxygen needed for metabolism can be fulfilled and calcium will be re-pumped to the sarcoplasmic reticulum. It causes the cessation of acetylcholine and decreases the motor plate. In these conditions, the muscle is experiencing optimal relaxation, pain reduction and effect on the muscle function improvement. ${ }^{19}$

The Kinesio taping application and myofascial release intervention in overcoming the ROM 
limitation on knee osteoarthritis has same function, it can restore the blood circulation through fascia stretching or even muscle, therefore the carrier pain and spasm in the muscles can be wasted. ${ }^{20}$ Moreover, this research finding showed that there is no significant effect about the combination as caused by the difference of application time. Kinesio taping application in this research was given continuously in a month and the taping replacement was conducted 3 times in a week. While the myofascial release application was not given continuously which was conducted 3 times in a week with 15 minutes in a duration. Besides, Kinesio taping has an effect in facilitating muscles and relieving the burden of the knee joint, thus it reduces the pain and restore muscle movement ${ }^{21}$ which is found in myofascial release.

\section{CONCLUSION}

Based on the findings, the conclusions of this study are the Kinesio taping application has an effect towards ROM improvement on elderly with knee osteoarthritis risk and the combination of myofascial release and Kinesio taping application has an effect towards ROM improvement on elderly with knee osteoarthritis risk. There is no significant effect on the application of Kinesio taping and its combination with myofascial release towards ROM improvement on elderly with knee osteoarthritis risk.

\section{CONFLICT OF INTEREST}

The authors have no conflicts of interest.

\section{ACKNOWLEDGEMENT}

The authors want to thank the headman of Puskesmas Kendal Kerep, Malang, Indonesia for the permission and guidance during the data collection of this study. The authors received no funding from any institution for this study.

\section{AUTHOR CONTRIBUTIONS}

AZW conceptualized and design the study, data collection, data analysis, data interpretation, and manuscript preparation. AY supervised in concept and design of the study, data analysis, data interpretation and manuscript preparation.

\section{REFERENCES}

1. Nugroho, W. (2008). Keperawatan Gerontik \& Geriatrik (Edisi 3 ed.). Jakarta: EGC

2. Yulianti, A., Baroya, N., \& Ririanty, M. (2014). Perbedaan Kualitas Hidup Lansia yang Tinggal di Komunitas. e- Jurnal Pustaka Kesehatan, 2(1), 1-2.
3. Widiarti, A. W., \& Sukadarwanto. (2016). Pengaruh Fisiotaping terhadap Peningkatan Kemampuan Fungsional pada Pasien Osteoarthritis. Jurnal Keterapian Fisik, 1(1), 28-29.

4. Isbagio, Harry. (2006). Osteoarthritis and Osteoporosis as Major Musculoskeletal Problems of Older Citizens in the 21st Century; Accessed April 5, 2010; from http://www. majalahfarmacia.com/rubrik

5. Andriyasa, K., \& Putra, T. R. (2012). Korelasi antara Derajat Beratnya Osteoarthritis Lutut dan Cartilage Oligomeric Matrix Protein Serum. Journal Peny Dalem, 13(1), 10-11.

6. Kase, Kenzo. Patricia Martin, A. Y. (2006). Kinesiotaping in pediatrics (2nd ed.). USA: LLC

7. Cho, H., Kim, E.-H., Kim, J., \& Yoon, Y. W. (2015). Kinesio Taping Improves Pain, Range of Motion, and Proprioception in Older Patients with Knee Osteoarthritis, 94(3), 192-200.

8. Werenski, J. (2011). The Effectiveness of Nyofascial Realese Technique in the Treatment of Myofascial Pain. Journal of Musculoskeletal Pain, 23, 27-35.

9. Sugiyono. (2010). Metode Penelitian Bisnis. Pendekatan Kuantitatif, kualitatif dan R \& D. Bandung: Alfabeta, 15(2010), 90.

10. Azizah, L. M. (2011). Keperawatan Lanjut Usia (Edisi 1 ed.). Yogyakarta: Graha Ilmu.

11. Maharani, E. P. (2009). Faktor-faktor Risiko Osteoartritis Lutut. In Tesis. Program Studi Magister Epidemiologi UNDIP : Semarang.

12. Eyler AA. (2003). Correlates of Physical Activity: Who's Active and Who's Not. Arthritis \& Rheumatism; 49(1): 13640

13. Arismunandar, R. (2015). The Relations Between Obesity and Osteoarthritis Knee in Elderly Patients. J Majority, 4(5), 110-116.

14. Reksoprodjo. (2005). Kumpulan Kuliah Ilmu Bedah. Jakarta. Bagian ilu Bedah Fakultas Kedokteran Universitas Indonesia. P: $534-551$

15. Khairani, Yulidar. (2013). Hubungan Umur, Jenis Kelamin, IMT, dan Aktivitas Fisik dengan Kejadian Osteoarthritis Lutut. Karya Tulis Ilmiah, Universitas Jambi, Jambi.

16. Malgaonkar, P.P. (2014). Short Therm Effect Of Mulligan”s Mobilization Versus Kinesio Taping On Knee Pain And Disability For Osteoarthritis Of Knee, Int J Physiother. 1(4): 233-240

17. Kuntono, H.P. (2011). Fisiotaping Metode Terkini Untuk Problem Nyeri, disampaikan dalam seminar nasional fisioterapi; Surakarta, 12 Maret 2011.

18. Wong JM, Khan T, Jayadev CS, Khan W, Johnstone D. (2012). Anterior cruciate ligament rupture and osteoarthritis progression. Open orthop J;6:295-300

19. Salvishah., Bhalara. (2012). "Myofascial Release". Internasional Journal of Health Sciences and Research. Gujarat

20. Aden, Z. S., Nurmawan, P. S., \& Indrayani, A. W. (2010). Penambahan Kinesiotaping pada Perlakuan Myofascial Release Technique Lebih Baik dalam Menurunkan Nyeri Fungsional pada Plantar Fascitis oleh karena Pemakaian Sepatu Hak Tinggi.

21. Prentice. (2013). Principles of athletic training $\left(15^{\text {th }}\right.$ ed).St. Louis: McGraw-Hill 